\title{
Formation of national self-consciousness of future musical art teachers in the process of their professional training
}

\author{
Vasyl Kovalchuk ${ }^{1, *}$, Tetiana Aheikina-Starchenko ${ }^{2, * *}$, Nataliia Chorna $^{2, * * *}$, and Svitlana Iskra $^{2, * * * *}$ \\ ${ }^{1}$ Department of Vocational Education and Technologies of Agricultural Production, Oleksandr Dovzhenko Hlukhiv National Pedagog- \\ ical University, 24 Kyevo-Moskovska Str., Hlukhiv, 41400, Ukraine \\ ${ }^{2}$ Department of Theory and Methods of Music Education, Vinnytsia Humanities Pedagogical College, 13 Nahirna Str., Vinnytsia, \\ 21000, Ukraine
}

\begin{abstract}
The authors of the paper analyze the definition of "national self-consciousness" and outline its structure, which includes self-esteem, socio-psychological expectations, and self-identification. From the point of view of the authors of the paper, the national self-consciousness of future musical art teachers includes three interrelated components. They are: an information-cognitive one, which involves mastering the system of general knowledge and special knowledge, as well as the possession of certain information regarding one's own self-identification; an emotional and value one, which reflects patriotic feelings, the desire for the national ideal, the value attitude towards the Ukrainian cultural heritage; and a reflexive and activity one, which characterizes the awareness of the nationality, awareness of oneself as a bearer of cultural values and heritage of the nation, and awareness of one's role in future professional activities. As a result of the analysis of the researches on the problem under our consideration, we made some conclusions about the ways of forming the national selfconsciousness of young people. The authors of the paper conducted a pedagogical experiment that allowed identify methodological aspects and suggest forms and methods that should be used in the training process to form the national self-consciousness of future teachers of musical art.
\end{abstract}

\section{Introductuon}

The state of Ukraine chose the path of its independence in 1991. The reform processes that have taken place in Ukraine for thirty years affected the national educational system. This system subsequently received transformations in the fields of education reforming, informatization, modernization of its structure, content and organization, updating its regulatory framework, and the like. Modern educational policy considers its strategic priority the formation of a nation that is constantly learning, assimilating democratic values at the same time. The nation, which develops its civil society and tries to affirm human-centered values in education [1].

An important role in the formation of such a nation belongs to higher pedagogical education, to the musical pedagogical education, in particular. This education aims at providing professional training for a competent music teacher capable of solving professional problems. It also aims at obtaining an active civic position in teachers who should be patriots of their country and be responsible for the preservation and development of the spiritual values of the nation. New social, economic, political, and cultural realities (that is, the processes of globalization, integration, informatization, changes in the system of moral

\footnotetext{
*e-mail: v.i_kovalchuk@ukr.net

**e-mail: agejkinatania@gmail.com

***e-mail: natachorna1969@gmail.com

****e-mail: iskrasviv@gmail.com
}

values, migration of young people abroad, circumstances related to Russian aggression, and the like) require a review and updating of methods, forms and means of music teachers training. These teachers should meet the demands of our modern civil society. In our opinion, this is the reason why a higher educational institution should become the center of formation of national self-awareness of future musical art teachers. Here, at this institution, every teacher should focus not only on teaching but also on his educational work, because teaching and education are a holistic syncretic pedagogical process. Here, at this institution, every teacher should focus not only on teaching but also on his educational work, because teaching and education are a holistic syncretic pedagogical process.

The Ukrainian state has had several vectors of its development - from the pro-Russian to the European one for these 30 years of independence. Subsequently, the confrontation in the Ukrainian politics found its reflection in the content of concepts aimed at formation of a new generation: the Concept of the national education system (1996), the Concept of national-patriotic education (2009), the Concept of the National Target Program of Patriotic Education of citizens for 2013-2017, the Concept of the Civic Teaching and Education in Ukraine (2012). Although every concept became a navigator for the formation of a system of national education of student youth in its own way, none of those concepts was fully implemented. The next attempt to outline the new directions 
and clarify the components of national-patriotic education was the Concept of national-patriotic education of children and youth (2015) and the Strategy of national-patriotic education (2019), which identified the national-patriotic education in Ukraine as one of the state and society priorities in the development of national identity.

The policy in the sphere of education in this country focuses on modern concepts of European countries, which pay special attention to cultural and national achievements: the UNESCO Convention on the Importance of Cultural Heritage for Society (2005), the UNESCO Convention on the Protection and Promotion of the Diversity of Cultural Expressions (2010), the Cultural Education Program, developed by the National Advisory Committee on Creative and Cultural Education (NACCCE) in England (2013) and others.

The concept of national awareness has existed in the Soviet pedagogical science since the 60-s of the XX-th century. The first scientific researches of those times considered the national awareness as one of the most essential features of the nation, but the theory of "a united Soviet people" due to the "merger of nations" [2], was in priority for Soviet ideology. That is why, in fact, the concept of the national awareness dealt mainly with the Russian nation that was more dominant within the boundaries of the USSR and the concept had a very significant ideological subtext. Following the collapse of the USSR, it became possible to research more objectively the issues of a nation, national self-awareness and identity, and patriotism.

The concept of national awareness (as well as the concepts of consciousness, self-consciousness) is the object of the study of many social sciences and humanities. Each of these sciences considers certain aspects of this construct regarding the vector of the research. In the context of our study, we are primarily interested in the philosophical, psychological and pedagogical aspects of this phenomenon.

Ukrainian philosopher F. Shandor, analyzing the meaning of the terms "consciousness" and "selfconsciousness", notes that modern the scientistsphilosophers study the formation of consciousness mainly through the formation of human self-consciousness as the ability and need to properly assess and analyze the behavior and activities of others. And then project those behaviors and activities o themselves. The author notes: if, with the help of consciousness, a person learns and perceives the world around him and if a person can orient in this world in a certain way, then the self-consciousness is mainly aimed at self-knowledge [3]. The researcher distinguishes the terms respectively - "national consciousness" and "national self-consciousness": national consciousness is a set of features of an individual, of a group or of a community. Those features arose in the process of communication with representatives of other national communities [4].

Modern Ukrainian scientists in the field of psychology (M. Boryshevskyi [5], A. Berezin [6], N. Yevdokymova [7], L. Spivak [8], A. Hafiatulina [9]) interpret national self-consciousness as a complex, multilayered, integral concept.
M. Boryshevskyi defines national self-consciousness as a person's awareness of himself as a part of a certain national (ethnic) community and his self-assessment as a carrier of national (ethnic) values. These values were formed in the process of long historical development of the national community, its self-realization as a subject of social reality. Unlike F. Shandor, the researcher makes the concepts of national consciousness and national self-consciousness equal, he considers them inseparable [10]. The psychologist includes self-esteem, harassment, socio-psychological expectations and "self-image" into the structure of national self-consciousness [5].

While studying the scout movement, as one of the factors in the formation and development of national selfconsciousness of youngsters, researcher N. Yevdokimova adds self-identification to the components identified by M. Boryshevskyi [7].

A. Berezin combines national self-consciousness with an ethnic one. He interprets national consciousness as a system of conscious ideas and assessments of the components of real life of the ethnos. These components make the ethnos different, at the same time consolidating them. When master this real life, the person realizes himself as a representative of the ethnos (nation). Consequently, the researcher specifics these components of the ethnos (nation)'s understanding. They are: ethnopsychological uniqueness of person's own community; psychological and cultural specifics of his ethnic group; kinship and identity with his own ethnic community; his personal ethnopsychic characteristics; he as a subject of his own ethnic group [6].

According to L. Spivak, the national consciousness of an individual is an integrative process of his selfknowledge, his emotional and value attitude to himself as a subject of a particular nation, as a bearer of values of his nation. As a result of this integrative process an individual regulates his own behavior in national interactions. The researcher singles out the following components in the structure of the national consciousness: a cognitive one (selfperception, self-analysis, self-understanding, conscious ideas of the individual about himself as a representative of a particular nation), an emotional-value one (self-feeling, self-assessment as a representative of the nation, attitude of the individual to himself as a subject of the nation, emotional-value self- attitude), and a regulatory one (selfregulation in interethnic and domestic interactions) and the core - the national "I" [8].

A. Hafiatulina defines national self-consciousness as a form of social consciousness that has a socio-political origin, on the one hand, and ethnic and cultural background, on the other hand; this social consciousness arises in the process of social life and life of the nation. The scientist, for the first time, defines the psychological features of the formation of national self-consciousness of students of different regional mentalities.

Ukrainian scholars in the field of pedagogy have begun to study the issue of forming the national selfconsciousness of pupils of secondary schools and students of higher educational institutions most actively since the proclamation of independence of Ukraine. 
V. Borysov in the first fundamental pedagogical study that reveals the theoretical and methodological foundations of the formation of national consciousness of pupils and students, considers national self-consciousness as a system of aggregate elements, which are in relations and connections with each other and in this way they form a certain unity. The researcher substantiates the structure of national self-consciousness with an emphasis on awareness of the peculiarities of the national culture of their nation; on awareness of the psychological characteristics of their nation; on awareness of their identity with the nation; on awareness of their own psychological characteristics; on self-awareness as a subject of their national community; on socio-moral self-esteem of the national [11]. V. Borysov's research gave impetus to the search for technologies for the formation of national self-consciousness of student youth by means of Ukrainian musical art (S. Borysova [12]), decorative and applied arts (O. Hevko [13]), fiction literature (V. Sokolova [14]), (L. Bilozub [15]), museum pedagogy (S. Voloshyn [16]), etc.

The national focus of the professional training of future music teachers as bearers of national cultural values is highlighted in the papers that highlight one of the contexts or means of the education of students' national consciousness. These contexts or means are the following: in the process of mastering Ukrainian folk song culture (R. Osipets [17]; by means of Ukrainian piano art (H. Sikora [18]; by means of folklore and ethnographic art (I. Pashchenko [19]); by means of musical art (V. Kupchyk [20]); in the process of the analysis of musical works (L. Vasylieva [21]); in the process of ethno-cultural training (A. Kozyr [22]); by means of folk song art (O. Krus [23]).

The scientific monograph of the specialists of the Department of the Musical Arts (V. O. Sukhomlynskyi National Universiti of Mykolaiv) on the problems of nationalpatriotic education of students by means of musical arts deserves our special attention. The monograph highlights the results of the approbation of the theoretical approach towards the effectiveness in the use of musical arts as a means of patriotic education of future teachers in the educational environment of a higher educational institution [24]. The monograph also pays attention to the research of K. Kucheruk-Drozdova [25] on the readiness of future musical art teachers to educate national self-awareness in their pupils. The researcher mentioned above substantiated, for the first time, the theoretical and methodological principles of the professional training of future musical art teachers in educating national self-awareness in their pupils.

The analysis of the scientific sources shows that the simultaneous (parallel) study of the phenomenon of national self-consciousness in philosophy, psychology and pedagogy contributes to the mutual enrichment of these sciences with new meanings and ideas, which affect their development. We can state that there is no established concept of national self-consciousness; scholars constantly clarify and deepen its content, depending on the social, economic, and political processes that take place in the state. The scientists consider the formation of the national self-consciousness of future musical art teachers from different angles and aspects, but they have not yet built a holistic system of this phenomenon, despite the growing scientific interest in the problem under our discussion. The issue of the national consciousness does not lose and will not lose its relevance as long as the processes of the development of the Ukrainian state take place.

While researching the issue we used the following methods: theoretical analysis, synthesis, generalization of philosophical and psychological-pedagogical literature. It allowed us clarify the essence of the concept of "national self-consciousness" and determine its structure; diagnostic methods (pedagogical observation, survey, questionnaire, testing, self-assessment method, creative tasks); pedagogical experiment to test the content, forms and methods of the formation of the national self-consciousness of future teachers of musical art.

\section{Results and discussion}

The theoretical analysis of the problem of the formation of national self-consciousness of future musical art teachers made it possible to consider this concept as an integrative combination of three interconnected components: an information-cognitive one, which involves mastering the system of general knowledge (language, history, traditions, mentality, and culture) and special knowledge (musical art, folklore, folk art, artistic heritage), as well as the possession of some certain information about individual's own self-identification; an emotional and value one, which reflects patriotic feelings, the desire for the national ideal, the value attention towards the Ukrainian cultural heritage; and a reflexive and activity one, which is characterized by awareness of nationality, awareness of individuals as the bearers of cultural values and heritage of the nation, awareness of their role in future professional activities.

The formation of national self-consciousness of future teachers of musical art, in our opinion, is possible under the conditions of obtaining both general knowledge and special musical knowledge, which fully characterize the national characteristics. According to L. Masol, the organic combination of universal (general human, multicultural), national (state) and regional (ethnolocal, of local history) components of education and upbringing is an unconditional priority of students' national orientation. $\mathrm{Mu}$ sical art is one of the most powerful means of education and influence, which allows a person to learn the national culture of his people and create his own spiritual world [26].

A musical work (like any work of art) is an artistic and information system. H. Lokarieva states that we form this system by means of synthesizing several types of information, namely: cognitive, artistic, aesthetic, intellectual, emotional, psychological, moral, ethical, individual and author, pragmatic and psycho-energetic. We express each type of information in an artistic form, and a work of art is both a carrier of information and a means of its transmission [27].

We determine national self-consciousness primarily by mental characteristics and axiological orientations. Thus, 
H. Tarasenko emphasizes that "knowledge without the transmission of value attention towards it is dead, and, later, even dangerous" [28]. Minding this statement, we consider an emotional and value component in the formation of national self-consciousness of future teachers of musical art as an extremely important one. This component is focused on creating a system of values (universal, national, professional), education of stable citizenship, patriotism, national ideal and value attention towards the Ukrainian cultural heritage on the basis of musical nationalism. We think it necessary to note that in the musical art, we associate the concept of "nationalism" with the depiction of musical ideas and motives by composers. These musical ideas and motives are identified with a particular country, region or ethnicity. S. Liudkevych was the first among the Ukrainian music studying scholars to use this term in the article "Musical nationalism". The article highlighted the issue of the formation of the national orientation in the Ukrainian music, comparing it with similar phenomena of other musical cultures [29].

The revival and development of national traditions involve communication with the national musical art. According to O. Rudnytska, the musical art improves the ability to see, feel, and contemplate, because the works of art offer artistic images directly addressed to the sensory sphere, emotions and feelings of man and aimed at "... "capturing" this sphere, make a person sympathize and empathize" [30]. This encourages the individual to creatively comprehend his own national essence, promotes the development of a sense of ethnic identity through perception and emotional experience, affects his consciousness, and determines spiritual values.

Regarding the scientific substantiation of researches on this problem, we note that national self-awareness is closely related to reflection as a process of self-knowledge and self-determination, awareness of nationality, selfunderstanding in the context of national culture. In particular, H. Padalka defines the leading role of the "artistic reflection" in the process of learning. The scholar interprets the artistic reflection as awareness of individual's own mental states in comparison with experiences reproduced in an artistic image, immersion into his own feelings, in comparison the content of artistic images with the results of the self-analysis of his inner life [31]. Thus, future teachers of musical art influence the formation of their own self-awareness in the process of the artistic reflection.

In their future professional activity music teachers should not only realize themselves as bearers of cultural values and heritage of the nation, but should also be ready to pass them to the next generation. Since all three components of national self-consciousness (knowledge, value attentions to it and actions) are interconnected, knowledge and values, which do not motivate students to action and active creativity, which are not fixed in their behavior and specific actions, lead to deformation of the national selfconsciousness of the individual.

Accordingly, we should consider the national selfconsciousness of future musical art teachers as an integrative trait of a personality. This trait involves mastering the system of general and special musical knowledge about the history, ideas, traditions, culture of their people, a clear patriotic position, awareness of belonging to their nation, reflection of emotional and value attitude towards the national musical heritage, desire for creative self-realization in the professional musical activities.

The organization of the experimental study involves, first of all, the diagnosis of the current state of national self-consciousness of future musical art teachers. We carried out this diagnosis with the students who learn at the specialty "Musical art" at the Communal Higher Education Institution "Vinnytsia Humanities Pedagogical College".

For this purpose, we identified the criteria, which correspond to the structural components of the national selfconsciousness of students, and we also developed the corresponding indicators. They are: the informationcognitive criterion (the integrity of general knowledge (language, history, traditions, mentality, culture), the amount of special musical knowledge (musical art, folklore, folk art), the development of cognitive abilities; the emotional and value criterion (a clear patriotic position, value attitude to the national cultural heritage, ability to emotional empathy); and the reflexive and activity criterion (identification of national affiliation; awareness of the role of future musical art teachers in the process of national education of youth; readiness for creative self-realization in the socio-cultural musical activities).

We used a complex of empirical research methods (observation, survey, questionnaire, testing, methods of selfknowledge, methods of self-assessment, creative tasks, etc.) to solve the research goals.

The results of the diagnosis showed that the real state of national self-consciousness of future musical art teachers is mainly at low (31\%) and medium (54\%) levels. We diagnosed a small number of students with a high level (15\%). Regarding the fact that the traditional content of higher music education does not provide the formation of national consciousness of future teachers of musical art of a high level, we think it essential to update the content, forms and methods of the educational process. And that was a very important component of our research.

The formation of the national consciousness of future musical art teachers involves the search for optimal means in the teaching process and in the educational work likewise. First of all, we speak about the subjects of professional training ("Music pedagogy", "History of Ukrainian music", "Ukrainian folk music", "Ethnomusic studying", "Voice training", "Basic special instrument", "Choral conducting", "Choral class") and educational activities.

The teaching process of the voice production of future music teachers have been characterized by professional and genre differentiation in recent decades. Traditionally, the vocal education in educational institutions was based only on classical singing. But, with the development of the music industry, we can observe a demand for such specializations as "Variety singing" and "Folk singing". However, as a rule, a teacher with an academic style of singing teaches also those students who have a pronounced folk voice and a folk manner of performing. It is not always possible to "retrain" these students, and as a result, they 
lose their folk style skills and, unfortunately, they do not succeed in academic singing.

The folk style of singing has deep roots in Ukraine. This style is inextricably linked to country's history, culture and customs. Therefore, we think that the loss of the natural folk style of singing is also the loss of a part of Ukrainian culture. That is why the issue of the need of the pedagogical staff of the specialization "Folk singing" is so acute. The teacher with appropriate education makes it possible to purposefully monitor the students with a pronounced folk style. This teacher trains students in his voice classes according to the methods of teaching of "Folk singing" using the repertoire of the Ukrainian musical heritage.

In modern conditions, the issue of involving young people in the folk tradition of Ukraine, in the preservation and promotion of its best examples is of vital importance. To achieve this goal, the educational and professional program of training of music students includes a number of subjects and practices, for example, the subject "Ukrainian folk music" precedes the folklore practical training named "Ethnomusic studying" Their task is to form a holistic system of knowledge about Ukrainian folklore in students, to reveal the meaning of the rituals of the people, to study the calendar-ritual songs, to arouse interest and love for folk music. According to A. Storozhuk, Ukrainian folk songs "have a power that allows modern youth to "touch" the past, to feel the pure spirit of many generations of our glorious national "family" tree, to deepen, to touch the awe of our ancestors, to comprehend the content of the thoughts of our ancestors in our modern, civilized and contradictory time" [32].

The student folklore practice solves the following tasks: to deepen the knowledge of various stylistic traditions of Ukraine, its dialect lines and trends in genres and stylistics; to form in future teachers of musical art a correct understanding of the current state of the development of folk music, which will help them develop the right attitude to the existing folk culture; to expand their ideas of the main features of the musical folklore of the Podillya region; to involve students in research activities, that is, to collect and preserve the samples of folk songs for their further use in student pedagogical work (demonstration and studying of folk songs at musical art lessons, expanding the repertoire of vocal ensembles, etc.). Our teaching experience shows that the knowledge of modern students of the Ukrainian folk repertoire is very limited; for these students the most popular, until recently, examples of Ukrainian songs, such as "Nese Halia vodu" or "Tsvite teren", are the real "discoveries". Knowledge of musical rituals is also very limited.

That is why the teaching of these subjects has an important impact on the formation of the students' national self-consciousness. Each folklore expedition has its theoretical and practical stages. At the first stage, the students (with the help of reference books and periodicals) get acquainted with the history of the place where the practice will take place, with its socio-economic and cultural state; the students also master the skills of collecting folklore materials and recording the work of the expedition. The collection of folklore materials (at the practical stage) involves identifying the conditions of folklore appearance in the village and the performers of folklore; drawing up a map-scheme of the settlement, where the students found out interesting folklore objects; audio and video recording of the folklore works, their certification and decoding; systematization of the musical material. Thus, on the bases of the study of samples of musical folklore of the Podillya region, young people acquire an understanding of the identity of the Ukrainian people, they enrich their musical impressions, develop their musical taste, and accumulate song "baggage" for their future work at school, because from each folklore practice held in the Vinnytsia region, future musical art teachers bring up to 50 new folklore texts.

For example, in the village of Shervone the students got a Kupala song "Oi, na Kupala vohon horyt", a Petrovska song "Oi, khodyla ta Daryna po poliu", wedding songs "Iak na korovai ishla", "Iak my korovai misyly", "Do kosy, bratiku, do kosy", "Oi, na dvori proso molotiat", household songs "A v horodi hrushechka", "Oi de bula pshenytsia", "Veselist, veselist", "Posiiala ohirochky", "Oi, barvin, ty barvin", "Sukha lishchyna"; in the village of Lisova Lysiivka the students got household songs "Polovyna sadu tsvite, polovyna - viane", "Odyn misiats skhodyt", "Dolyna shyroka, kalyna vysoka", "Oi, povii, vitre, z yaru"; in the village of Demydivka - household songs "Synia kvitka", "Ne sama-ne sama" and others.

In order to promote Ukrainian folk songs, the college has folklore ensembles, the repertoire of which consists of the folklore of the Podillya region - both ceremonial and domestic folk songs; these songs are performed without any musical accompaniment in the local folk (authentic) manner, typical for the Podillya region.

The obligatory requirement of the subject "Voice production" is the performance of the Ukrainian folk song acapella. The learning purpose of this task is the ability of pure intonation; the educational purpose is the love for folk music of the Ukrainian people. When choosing a repertoire for performing a work by a modern composer, teachers select the works by contemporary authors of the Podillya region: H. Biliavskyi ("Ukraina", "Liuba Vinnytsia", "Pisnia nad Podilliam", "Velychni dzvony", "Nasha mriia"), E. Brylin ("Mii ridnyi krai", "Symvoly Ukrainy", "Letily husonky", "Try dorohy", "Topolyna vulytsia"), O. Ianushkevych ("Na krylakh mrii”, "Ie lysh vy", "Lukasheva sopilka", "Zlety, liubove", "Liubystok", "Shche ne osin", "Oi pryletily dva holubochky") and others. Creative meetings with fellow composers, attending their master classes, acquaintance with new musical works; all these activities not only inspire and fascinate students, but also contribute to the understanding of their nationality.

The song repertoire for children has changed radically in recent decades. Works of the "Soviet era" are less and less studied. More and more songs for children of Ukrainian composers are studied: M. Dremliuha ("Vesniani kraplyny", "Rankova pisnia", "Oi zahraly komari”, "Stoit kozlyk nad vodoiu"), L. Dychko ("Zyma", "Pryhoshchaites, ptashky!"), A. Filipenko ("Veselyi muzykant", "Kurchata", "Ziablyk", "Kozlyk v poli tant- 
siuvav", "Zaiko", "Veseli cherevychky", "To snizhynky, mov pushynky", "Uziala lysychka skrypku"), M. Haivoronskyi ("Yikhav strilets na viinonku", "U stepu", "Zyma i vesna", "Vzhe lito", "Za ridnyi krai"), L. Revutskyi ("Sonechko", "Idy, idy, doshchyku", "Kolyskova", "Pisnia"), Yu. Rozhavskyi ("Vesnianochka", "Shcho skazav meni leleka"), Ya. Stepovyi ("Snizhynky", "Shchebetala ptashechka", "Misiats yasnesenkyi"), K. Stetsenko ("Vechirnia pisnia", children's opera "Lysychka, Kotyk i Pivnyk"), as well as children's songs by contemporary composers H. Biliavskyi ("Kolorovi parasolky", "Pisenka nadii", "Bakteriia", "Harnyi svit", "Litolitechko", "Shkilnyi dzvinok"), E. Brylin ("Slukhai, vesnonko", "Romans Perepilky", "Velykyi i malyi", "Nevdalyi vystup", "Mamyna usmishka"), L. Horova ("Muzyka zvuchyt", "Vidchynylosia zhyttia", "Dvi pisenky", "Mriinytsia", "Dobryi vechir, liudy", "Yide, yide Boh"), O. Ianushkevych ("Veselkova pisnia", "Pisenka pro zariadku", "Lito zolote", "Chomuchky", "Dytynstva svit", "Treba mriiaty zavzhdy", "Mama i ya"), V. Kolotii ("Bukvaryk", "Topolyna pisnia", "Drimaiut sela"), I. Kyrylina ("Spivaiut dity", "Zelene slonenia", "Bychok ta yizhachok", "Zasmutylos koshenia", "Pisenka"), N. Mai ("Mii bukvaryk", "Mamyna sorochka", "Zolotava osin", "Sopilochka"), M. Mazur ("Kolorovyi svit", "Do sontsia, do neba", "Chas", "Nova mashyna"), A. Mihai ("Multyky", "Sim not", "Podarunok", "Khytalochka-hoidalochka"), O. Peniuk ("Mykolai ide", "Zaichyk", "Mamyni rushnyky"), etc. These songs are written on the lyrics of modern authors. The update of the children's song repertoire is due to the implementation of the subject "Art". The teachers of the department initiated and launched a competition of amateur composer's skills "Zolota Nota" for future musical art teachers. It was done in order to help students better understand the nature of the Ukrainian children's song. The best competition works on the lyrics of domestic poets are later presented in the musical collection "Musical colors of childhood". Competitions of this kind encourage students to creativity; they create a "situation of success", and give an impetus for student creative self-realization.

The education of the younger generation changed its vector to a national-patriotic trajectory with the proclamation of independence of Ukraine. Special music subjects required a revision of the repertoire policy; in particular they required changes in the curriculum on the subject "Basic musical instrument". Works based on national roots play a very important role in the formation of national self-consciousness. For instance, the educational potential of national folklore in the domestic piano literature is represented by a large independent section, numerous adaptations of Ukrainian folk songs and dances.

Today we speak about the shift from the professionalization of education to its educational principles [33] in the educational process of playing musical instruments.

Accordingly, there appears a need to enrich the piano repertoire by including works by Ukrainian composers V. Barvinskyi, V. Bezkorovainyi, I. Berkovych, V. Bibik, O. Bilash, E. Brylin, B. Filts, M. Fomenko, V. Hrudyn, M. Karminskyi, M. Kolessa, L. Kolodub, Zh. Kolodub, A. Kos-Anatolskyi, M. Kravtsiv-Barabash, B. Kudryk,
K. Kuklovskyi, H. Kurkov, V. Kyreiko, B. Liatoshynskyi, Ya. Lopatynskyi, Z. Lysko, F. Nadenenko, N. Nizhankivskyi, V. Podvala, V. Pukhalskyi, L. Revutskyi, Yu. Rozhavska, S. Turkevych, M. Tutkovskyi, V. Vytvytskyi, Ya. Yaroslavenko, H. Sasko, R. Savytskyi, I. Shamo, S. Shevchenko, Yu. Shchurovskyi, D. Sichynskyi, M. Skoryk, I. Sonevytskyi, M. Stepanenko, M. Sylvanskyi, V. Sylvestrov and others. Updating the musical and pedagogical repertoire is only the first step towards the realization of the value of the national cultural heritage. While working on each work, the student must understand, get experience and "appropriate" the emotions that the composer wanted to convey. A piece of music that has not found an emotional response in a student, respectively, cannot have an educational impact on him. Future musical art teachers will present the results of their work during the annual concert "Music of Ukrainian composers"; at this concert students and teachers perform vocal and instrumental works by Ukrainian composers. Creative communication and emotional mutual enrichment contribute to the awareness of future musical art teachers of their role in future professional activities.

In addition to works of foreign choral classics, the repertoire was replenished with samples of Ukrainian folk songs and choral works of Ukrainian composers. These works are by A. Avdiievskyi ("Pavochka khodyt", "Dibrova zelena", "Chuiesh, brate mii", "Tsvite teren", "Oi tam za lisochkom", "Na potochku prala", "Handzia", "Dumy moi, dumy"), M. Kolessa ("Oi umer staryi batko", "Utoptala stezhechku", "Iakby meni cherevyky", "Bulo kolys na Vkraini”, "A ya pidu v polonynu"), M. Leontovych ("Shchedryk", "Kozaka nesut", "Dudaryk", "Izza hory snizhok letyt", "Zhenchychok-brenchychok", "Haiu, haiu, zelen rozmaiu"), S. Liudkevych ("Hahilka", "Oi, Moroze, Morozenku", "Bodai sia kohut znudyv", "Pro Bondarivnu", "Oi zatsvily fiialochky"), M. Lysenko ("Oi ne svity, misiachenku", "Oi khodyla divchyna berezhkom", "Verkhovyno, svitku ty nash", "A vzhe vesna", "Sontse nyzenko"), K. Stetsenko ("Svitiat zori", "To ne buinyi viter", "Chuiesh, brate mii") and others.

The educational institution also initiated and launched annual workshops for teachers of music in the region under the general name "U koli kanoniv" ("In the circle of canons"). The purpose of these workshops is to popularize choral art in schools, to involve pupils and students in studying the heritage of the world and domestic choral art, to get acquainted with the methodology and experience of choirs (the best choirmasters of the city and the region), and to present new music textbooks for school choirs. In this way, workshops, with the participation of student choir, promote the students' awareness of themselves as representatives of the Ukrainian nation and foster their sense of patriotism.

We consider the project method, which ends in a creative product and involves the presentation of the results of individual, group or collective work, one of the effective methods of forming the national self-consciousness of future musical art teachers. For example, students not only acted as researchers, but also tried themselves as bloggers in the project on the history of Ukrainian music "Ukrainian 
musical culture of the 50-80s. Song heritage". They video recorded the material, illustrated it with videos of works on the research topic. All materials were mounted in a twopart video series and posted on YouTube and Facebook. The result of the project was the student assimilation of musical cultural values of this era.

Mass-media have a significant impact on the formation of student self-awareness. Modern youth lives in massmedia, in music information in particular, and prefers modern world's pop and rock music. In order to communicate with young people in one musical language, the students were offered an experimental music project. The famous Ukrainian folk songs "Podolianochka", "Oi dub, dub", "Vasylyna" were performed in the academic manner, but with modern electronic dubstep support in the project. Such reformatting of contributes to obtaining a positive educational effect, to attracting students to choral singing as a national tradition.

One of the modern forms with educational influence is a challenge (a genre of Internet videos, in which a blogger performs tasks on a video camera, shows them online, and then offers to repeat the task to his acquaintances or an unlimited number of users). The students of the college launched several challenges, which involved students and teachers vocal and choral groups: in honor of the 100th anniversary of the first performance of the choral arrangement of "Shchedryk" by M. Leontovych (20162017); known worldwide as "Carol of the Bells"; flash mob \#Chervonaruta50challenge, launched in support of the 50th anniversary of the song "Chervona ruta" of the famous Ukrainian composer V. Ivasiuk (2020). The educational influence and uplift of those challenges cause "responses" of a large number of singers from Ukraine and around the world.

While studying the subject "Music pedagogy" students get acquainted with the history of musical and pedagogical education in Ukraine, they conduct research activities to study the work of Ukrainian composers and musicians. Future musical art teachers present their research on the musical and pedagogical activities of Ukrainian composers (F. Kolessa, M. Leontovych, S. Liudkevych, M. Lysenko, Ya. Stepovyi, K. Stetsenko, I. Vorobkevych) at international scientific and practical conferences. Students' involvement in the study of the historical past of Ukraine and of the musical heritage educates in them a sense of pride for the spiritual achievements of their nation.

We also consider the participation of students not only in regional and national, but also in international competitions and festivals one of the means of involving future musical art teachers in the promotion of national choral music. At these competitions and festivals students feel a special responsibility to represent their country and use national symbols with great pride in the most solemn moments - when they unfurl the National Flag of Ukraine and perform the National Anthem of Ukraine.

At the end of the formative stage of our experimental work a control monitoring. Its results showed that the introduction into the educational process of the proposed, forms and methods of forming national self-consciousness of future teachers of musical art contributed to positive

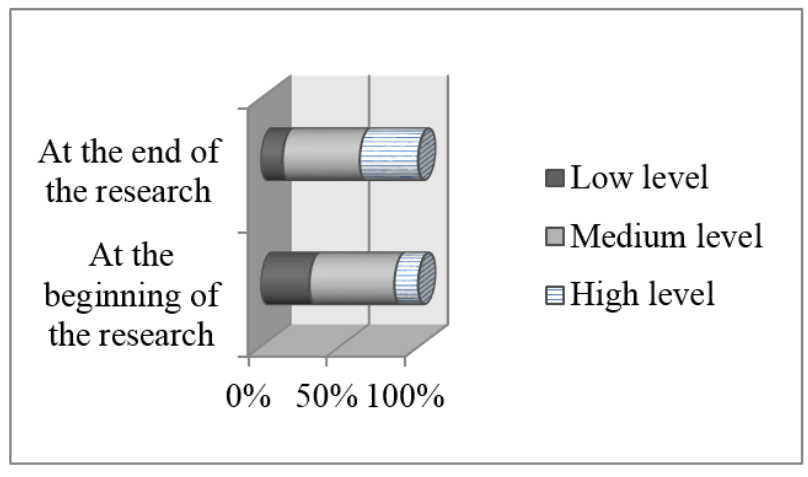

Figure 1. Dynamics in the formation of national consciousness of future musical art teachers

changes. In particular, we fixed an increase in the number of students with a high level of national self-consciousness from $15 \%$ to $37 \%$, while the number of future specialists with a low level decreased from $31 \%$ to $14 \%$ and the medium level - from $54 \%$ to $49 \%$. The results of our experimental research study are presented in the diagram (figure 1).

The qualitative and quantitative results obtained in the course of the research allow us speak about the effectiveness and prospects of the proposed methodological aspects of the formation of the national self-consciousness of future teachers of musical art.

\section{Conclusions}

As the result of the theoretical analysis, we have determined that the national self-consciousness of future teachers of musical art is an integrative property of any individual. It includes mastering the system of general and special musical knowledge about the history, ideas, traditions, culture of their people, a clear patriotic position, awareness of belonging to their nation, reflection of emotional and value attitude to the national musical heritage, desire for the creative self-realization in professional music activities.

We have identified the criteria that correspond to the structural components of national self-consciousness of students and developed its indicators: an informationcognitive criterion (the integrity of general knowledge (language, history, traditions, mentality, culture), the amount of special musical knowledge (music, folklore, folk art), and the development of cognitive abilities); an emotional and value criterion (the clear patriotic position, the value attitude to the national cultural heritage, and the ability to emotional empathy); a reflexive and activity criterion (the identification of nationality; the awareness of the role of a future teacher of musical art in the process of the national education of youth; the readiness for creative self-realization in socio-cultural musical activities).

We have proposed forms and methods for use in the process of professional training to form the national selfconsciousness of future teachers of musical art: cultural and artistic projects; challenges; flash mobs; competitions of amateur compositions; artistic meetings with Ukrainian 
composers (including the composers of Vinnytsia region); attending their master-classes; organizing workshops with the participation of student choirs, music teachers and the best choirmasters of the region; participation (as performers) of future musical art teachers in the concerts of Ukrainian composers; participation of the vocal and choral groups not only in regional and national, but also in international competitions and festivals; presentation of scientific researches on the musical and pedagogical activity of Ukrainian composers at the Ukrainian and international scientific and practical conferences.

We have identified the factors that provide the national content of the professional training of future teachers of musical art, including: updating the music and pedagogical repertoire by increasing the share of the national component; making changes to the program requirements of the subjects "Voice production", "Choral class", "Basic musical instrument", a particular requirement - the obligatory performance of a work by a Ukrainian composer; implementation of new subject "Music pedagogy" and folklore practice "Ethnomusic studying"; replenishment of the staff with folk vocal specialists who have appropriate education to teach the subject "Voice production" for the students with a pronounced folk style of singing.

We have experimentally proved the effectiveness and prospects of our proposed content, forms and methods of forming the national self-consciousness during their implementation in the process of professional training of future teachers of musical art.

The research presented, of course, does not cover all aspects of the problem. The prospects for further research include updating the content of music subjects in accordance with the modern educational standards and programs, taking into account the personal approach in teaching. The prospects also include developing and implementing a system of integrative courses that will more effectively develop the national self-consciousness of future musical art teachers.

\section{References}

[1] V. Kremen, V. Luhovyi, A. Hurzhii, O. Savchenko, Natsionalna dopovid pro stan i perspektyvy rozvytku osvity v Ukraini (National report on the state and prospects of education in Ukraine) (Pedahohichna dumka, Kyiv, 2016)

[2] V. Hrynevych, Ukrainskyi tyzhden 46, 54 (2012)

[3] F. Shandor, Vyshcha osvita Ukrainy 2, 73 (2011)

[4] F. Shandor, Vyshcha osvita Ukrainy 4, 17 (2011)

[5] M. Boryshevskyi, Sotsialno-psykholohichnyi vymir demokratychnykh peretvoren $v$ Ukraini (Sociopsychological dimension of democratic transformations in Ukraine) (Ukrainskyi tsentr politychnoho menedzhmentu, Kyiv, 2003)

[6] A. Berezin, Ph.D. thesis, G. S. Kostiuk Institute of Psychology of the National Academy of Educational Sciences of Ukraine (2002)
[7] N. Yevdokymova, Ph.D. thesis, G. S. Kostiuk Institute of Psychology of the National Academy of Educational Sciences of Ukraine (2005)

[8] L. Spivak, Ph.D. thesis, National Pedagogical Dragomanov University (2016)

[9] A. Hafiatulina, Ph.D. thesis, Borys Grinchenko Kyiv University (2017)

[10] M. Boryshevskyi, Osobystist u vymirakh samosvidomosti : monohrafiia (Personality in the dimensions of self-awareness: a monograph) (Ellada, Kyiv, 2012)

[11] V. Borysov, Ph.D. thesis, National Pedagogical Dragomanov University (2005)

[12] S. Borysova, Ph.D. thesis, Luhansk Taras Shevchenko National University (2002)

[13] O. Hevko, Ph.D. thesis, National Pedagogical Dragomanov University (2003)

[14] V. Sokolova, Ph.D. thesis, Vasyl Stefanyk Precarpathian National University (2005)

[15] L. Bilozub, Visnyk Zaporizkoho natsionalnoho universytetu: zbirnyk naukovykh prats. Pedahohichni nauky (2013)

[16] S. Voloshyn, Ph.D. thesis, Volodymyr Dahl East Ukrainian National University (2019)

[17] R. Osypets, Ph.D. thesis, Institute of Problems of Education of the National Academy of Educational Sciences of Ukraine (2000)

[18] H. Sikora, Aktualni pytannia mystetskoi pedahohiky 2, 115 (2013)

[19] I. Pashchenko, Ph.D. thesis, Volodymyr Dahl East Ukrainian National University (2014)

[20] V. Kupchyk, Problemy pidhotovky suchasnoho vchytelia 14, 266 (2016)

[21] L. Vasylieva, Naukovyi visnyk MNU imeni V. O. Sukhomlynskoho. Pedahohichni nauky 4 (59), 114 (2017)

[22] A. Kozyr, Humanizatsiia navchalno-vykhovnoho protsesu 1 (87), 39 (2018)

[23] O. Krus, Molod i rynok 2 (181), 157 (2020)

[24] Natsionalno-patriotychne vykhovannia studentiv $v$ osvitno-vykhovnomu seredovyshchi universytetu zasobamy muzychnoho mystetstva (National-patriotic education of students in the educational environment of the university by means of musical art) (RALpolihrafiia, Mykolaiv, 2018)

[25] K. Drozdova-Kucheruk, Ph.D. thesis, Vinnytsia Mykhailo Kotsiubynskyi State Pedagogical University (2020)

[26] L. Masol, Informatsiinyi zbirnyk MON Ukrainy 9, 7 (2004)

[27] H. Lokarieva, Visnyk Zaporizkoho natsionalnoho universytetu 3 (21), 179 (2013)

[28] H. Tarasenko, B. Nesterovych, Visnyk Zhytomyrskoho derzhavnoho universytetutu 21, 12 (2005)

[29] S. Liudkevych, Doslidzhennia, statti, retsenzii, vystupy (Research, articles, reviews, speeches), Vol. 1 (Dyvosvit, Lviv, 1999)

[30] O. Rudnytska, Pedahohika: zahalna ta mystetska (Pedagogy: general and art) (Navchalna knyha - 
Bohdan, Ternopil, 2005)

[31] H. Padalka, Pedahohika mystetstva (Teoriia $i$ metodyka vykladannia mystetskykh dystsyplin) (Pedagogics of art (Theory and method of teaching of artistic disciplines) (Osvita Ukrainy, Kyiv, 2008)
[32] A. Storozhuk, Pedagogical Sciences 4 (95), 208 (2018)

[33] V. Kireieva, N. Logvynenko, Nauka. Relihiia. Suspilstvo 1, 92 (2012) 